\title{
PENJADWALAN MATAKULIAH MENGGUNAKAN ALGORITMA GREEDY \\ (STUDI KASUS PENJADWALAN SEMESTER GANJIL 2017-2018 INFORMATIKA ITENAS)
}

\author{
Yasmin Math Khader ${ }^{1}$, Youllia Indrawaty Nurhasanah ${ }^{2}$, Afriyanti Dwi Kartika ${ }^{3}$ \\ Program Studi Teknik Informatika, Jurusan Informatika \\ Institut Teknologi Nasional \\ Jl. PKH. Mustopha No.23, Neglasari, Cibeunying Kaler, Bandung. \\ yasminmathkhader@gmail.com³ ${ }^{3}$ youllia@itenas.ac.id ${ }^{2}$, afriyantidwikartika@itenas.ac.id ${ }^{3}$
}

\begin{abstract}
Abstrak
Penjadwalan mata kuliah menjadi salah satu masalah di dunia perkuliahan. Ruangan yang terbatas, waktu dosen yang harus disesuaikan, jadwal mata kuliah yang banyak menyebabkan penjadwalan harus disusun secara hati-hati dan teliti. Hal tersebut mengakibatkan pembuatan penjadwalan mata kuliah secara manual membutuhkan waktu yang lebih lama sehingga dapat menghambat berbagai hal. Tujuan dari penelitian ini adalah untuk mengimplementasikan algoritma greedy sehingga didapatkan hasil penjadwalan perkuliahan yang tidak memiliki bentrok, kapasitas kelas dan jumlah mahasiswa dapat menyesuaikan. Sehingga dalam penelitian ini akan menggunakan Algoritma Greedy. Algoritma Greedy adalah algoritma komputasi untuk mencari jarak terpendek, dari teori tersebut kemudian diadposi menjadi algoritma komputasi untuk mencari nilai terendah dalam kombinasi pada penjadwalan matakuliah. Dengan menerapkan algoritma greedy pada sistem, sistem dapat menghasilkan jadwal matakuliah tanpa adanya bentrok, kapasitas kelas dan jumlah mahasiswa dapat menyesuaikan. Output dari sistem ini adalah jadwal matakuliah yang tersimpan di kalender.
\end{abstract}

Kata Kunci : Greedy, Penjadwalan, Matakuliah

\begin{abstract}
Arranging college subject becomes one of the problem for the institute. Limited of class rooms, lecturer's time that should be adjusted, many courses should be attended by college student cause arranging college subject should carefully arranged. Making manual schedule need more time and
\end{abstract}

obstructing lectures. The purpose of this study is to implement greedy algorithms so that the results of scheduling lectures that have no clash, class capacity and number of students can adjust. Greedy algorithm is a computational algorithm to find the shortest distance, from the theory then diadposi into computational algorithms to find the lowest value in the combination of scheduling a class. By applying the greedy algorithm to the system, the system can generate class schedules without clashes, class capacity and number of students can adjust. The output of this system is the course schedule stored in the calendar.

Keyword : Greedy, Scheduling, College Subject.

\section{Pendahuluan}

\section{I.1 Latar Belakang}

Dalam kegiatan penyusunan jadwal matakuliah yang dilakukan secara manual, dibutuhkan ketelitian dan waktu yang tidak sebentar, dan seringkali terdapat berbagai masalah seperti banyaknya jadwal matakuliah yang harus disusun, jumlah ruangan yang terbatas, dan kesanggupan dosen untuk mengajar pada jadwal tertentu, sehingga dapat menyebabkan bentroknya jadwal mata kuliah ataupun adanya ketidaksesuaian jadwal mata kuliah. Penyelesaian masalah penjadwalan mata kuliah dalam jumlah yang sangat besar hingga saat ini masih menjadi permasalahan yang rumit untuk diselesaikan secara manual (Wiga dkk, 2013).

Oleh karena itu, karena adanya berbagai macam kesulitan yang dapat terjadi pada saat di lakukannya pembuatan jadwal matakuliah secara manual, dibuat

\section{Yasmin Math Khader, Youllia Indrawaty Nurhasanah, Afriyanti Dwi Kartika}


penelitian untuk mengimplementasikan algoritma greedy sehingga di dapatkan hasil penjadwalan perkuliahan yang tidak memiliki bentrok. Algoritma greedy merupakan salah satu algoritma yang paling popular dalam menyelesaikan kasus permasalahan optimasi. Greedy adalah algoritma yang praktis, ringkas, dan fleksible sehingga dapat digunakan pada kasus persoalan optimasi. Hal ini dapat di buktikan dengan terdapatnya beberapa penelitian yang menggunakan greedy sebagai algoritma dalam penyelesaian masalah, misalnya Penerapan Algoritma Greedy untuk Menentukan Penjadwalan Kelas Gedung Labtek V ( Albhikautsar, 2013), Sistem Pencarian Hotel Berdasarkan Rute Perjalanan Terpendek Dengan Mempertimbangkan Daya Tarik Wisata Menggunakan Algoritma Greedy (Audrey, 2015), Penerapan Algoritma Greedy Pada Mesin Penjual Otomatis (Vending Machine) (Alamsyah. 2014) dan lain-lain. Penerapan algoritma ini adalah membentuk solusi langkah per langkah (step by step).

\section{I.2 Rumusan Masalah}

Bentrok antara salah satu jadwal mata kuliah dengan yang lainya merupakan suatu permasalahan yang sering terjadi dalam melakukan penjadwalan mata kuliah. Penjadwalan mata kuliah merupakan kegiatan administratif yang penting dan memakan waktu yang cukup lama (Simamora, 2015). Penelitian ini juga diharapkan mampu membuat perangkat lunak yang menjadi sumber informasi jadwal mata kuliah bila mana ada kegiatan kampus atau kegiatan seorang dosen yang mempengaruhi jadwal mata kuliah. Berdasarkan dari masalah tersebut terdapat rumusan masalah yaitu :

1. Bagaimana cara penerapan algoritma greedy untuk mendapatkan hasil penjadwalan perkuliahan yang tidak memiliki bentrok, kapasitas kelas dan jumlah mahasiswa dapat menyesuaikan.

2. Bagaimana cara penerapan constraint untuk data dosen, mata kuliah, ruangan, dan jam kuliah.

\section{I.3 Batasan Masalah}

Batasan masalah dalam penelitian ini adalah: (1) Sistem mengelola penjadwalan kuliah untuk Program Studi Teknik Informatika dan Program Studi Teknik Informatika Institut Teknologi Nasional.
Penjadwalan kuliah dilakukan untuk semester regular (gasal dan genap).

\section{KAJIAN LITERATUR}

\section{II.1 Algoritma Greedy}

Algoritma greedy merupakan salah satu jenis algoritma Best First Search yang paling sederhana dengan hanya memerhitungkan biaya perkiraan (estimated cost) saja, yakni $\mathrm{f}(\mathrm{n})=\mathrm{h}(\mathrm{n})$. Greedy algorithm adalah kelompok algoritma yang selalu mengambil penyelesaian sementara/lokal yang terbaik dalam setiap langkahnya untuk menyelesaikan suatu permasalahan. Pilihan terbaik akan diambil pada setiap langkah tanpa perlu memikirkan bagaimana pengaruhnya terhadap penyelesaian secara keseluruhan (Hendarto, Janoe, 2007).

\section{II.2 Penjadwalan}

Berdasarkan Kamus Besar Bahasa Indonesia, jadwal merupakan pembagian waktu berdasarkan rencana pengaturan urutan kerja. Jadwal juga didefinisikan sebagai daftar atau tabel kegiatan atau rencana kegiatan dengan pembagian waktu pelaksanaan yang terperinci. Sedangkan penjadwalan merupakan proses, cara, perbuatan menjadwalkan atau memasukkan dalam jadwal (Departemen Pendidikan dan Kebudayaan, 1995). Definisi yang lebih umum adalah menugaskan satu kumpulan peristiwa (kuliah, kendaraan, acara-acara publik, dll) dengan kumpulan terbatas sumber dari waktu ke waktu sedemikian rupa untuk memenuhi kendala (batasan/constraint) yang telah ditetapkan, kendala ini dapat dikategorikan sebagai hard constraint dan soft constraint, di mana hard constraint memiliki prioritas yang lebih tinggi dari pada soft constraint. Terdapat dua batasan dalam penyusunan penjadwalan kuliah yang dikemukakan oleh Burke dkk. (2002), yaitu : hard constraint (harus terpenuhi) dan soft constraint (diupayakan untuk terpenuhi). Hard constraints merupakan batas-batas yang harus diterapkan pada penjadwalan mata kuliah dan harus dipenuhi. Sebuah solusi hanya dapat dikatakan sahih dan valid apabila dalam solusi tersebut sama sekali tidak ada hard constraint yang terlanggar. Hard constraints yang ditetapkan dalam pembangunan sistem penjadwalan matakuliah berbasis algoritma greedy adalah sebagai berikut :

1. Satu (1) dosen dapat berada pada dua (2) kelas atau lebih pada waktu yang bersamaan.

Yasmin Math Khader, Youllia Indrawaty Nurhasanah, Afriyanti Dwi Kartika 
2. Satu (1) ruangan tidak bisa digunakan untuk dua (2) atau lebih mata kuliah pada waktu yang bersamaan.

3. Satu (1) kelas tidak bisa memiliki dua (2) jadwal mata kuliah atau lebih pada waktu yang bersamaan.

4. Mata kuliah teori harus berada pada ruang kelas reguler dan mata kuliah praktikum harus berada pada ruang kelas laboratorium.

5. Hari jum'at pukul 11:00-13:00 tidak bisa dipakai untuk kegiatan belajar.

6. Hari kuliah adalah hari senin hingga sabtu dan jam kuliah dimulai dari jam 07:00-17:50 WIB.

7. Satu (1) sks mata kuliah berdurasi selama 1 jam (50 menit perkuliahan ,10 menit istirahat).

Berbeda dengan hard constraint, soft constraint merupakan kendala yang tidak selalu dapat terpenuhi dalam proses pembentukan jadwal, akan tetapi meskipun tidak harus terpenuhi, jadwal yang dihasilkan harus semaksimal mungkin berusaha memenuhi ketentuan soft constraint.

Dosen dapat meminta waktu jadwal mengajar tertentu yang diinginkan. Berdasarkan penjelasan tersebut, terdapat sejumlah batasan-batasan tertentu, dimana pada batasan-batasan tersebut terdapat batasan yang tidak boleh dilanggar atau harus terpenuhin. Batasan tersebut merupakan ukuran kualitas dari penjadwalan matakuliah, sehingga suatu jadwal matakuliah yang optimal dapat terbentuk

\section{ANalisis dan Perancangan}

\section{III.1 Analisa Kebutuhan Sistem}

Dalam membangun sistem penjadwalan matakuliah dengan algoritma greedy, dibutuhkan spesifikasi software dan hardware tertentu agar proses membangun sistem dapat berjalan dengan lancar, dan sistem juga memiliki kebutuhan yang harus dimiliki, berikut adalah identifikasi kebutuhan tersebut.

\section{III.2 Identifikasi Kebutuhan Sistem}

Pada tahap ini dilakukan identifikasi untuk mengetahui kebutuhan dan fungsi sistem yang diharapkan. Berikut ini merupakan kebutuhan utama yang diharapkan pada sistem penjadwalan matakuliah dengan algoritma greedy, yaitu diantaranya adalah sebagai berikut :

1. Sistem mampu menghasilkan jadwal matakuliah tanpa adanya bentrok sama sekali didalam jadwal yang dihasilkan, meliputi tidak adanya bentrok dosen, bentrok ruangan dan bentrok waktu.

2. Sistem mampu menyesuaikan jumlah mahasiswa dengan kapasitas kelas.

Sistem mampu mengecualikan dosen pada jam dan hari tertentu.

\section{A. Identifikasi Kebutuhan Software}

Dalam membangun sistem penjadwalan matakuliah dengan algoritma greedy, dibutuhkan berbagai macam perangkat lunak, perangkat lunak tersebut diantaranya adalah sebagai berikut :

1. Windows 10 64-bit, dibutuhkan sebagai operating system yang digunakan untuk membuat dan menjalankan aplikasi.

2. Slim Framework, sebagai Framework PHP yang digunakan dalam perancangan sistem yang berbasis website.

3. XAMPP, sebagai server lokal untuk proses pengetesan sistem dan juga untuk menyediakan database yang berbasis MySQL.

4. HeidiSQL, sebagai aplikasi untuk mengakses dan membuat database.

5. Google Chrome, sebagai alat untuk membuka sistem yang dibangun.

6. Sublime Text, sebagai alat untuk penulisan dan pengkodean sistem yang dibangun.

\section{B. Identifikasi Kebutuhan Hardware}

Dalam membangun sistem penjadwalan matakuliah dengan algoritma greedy, dibutuhkan perangkat keras, perangkat keras terpenting yang dibutuhkan dalam pembangunan sistem adalah laptop, dengan spesifikasi sebagai berikut :

- Laptop Dell Inspiron 5448, dengan spesifikasi :

- Sistem Operasi Windows 10 Pro,

- Intel® Core ${ }^{\mathrm{TM}}$ i5 5200U Processor,

- RAM 8GB,

- Harddisk Internal 500GB 


\section{Perancangan}

Perancangan dijelaskan menggunakan flowchart yang dapat dilihat pada gambar 1 .

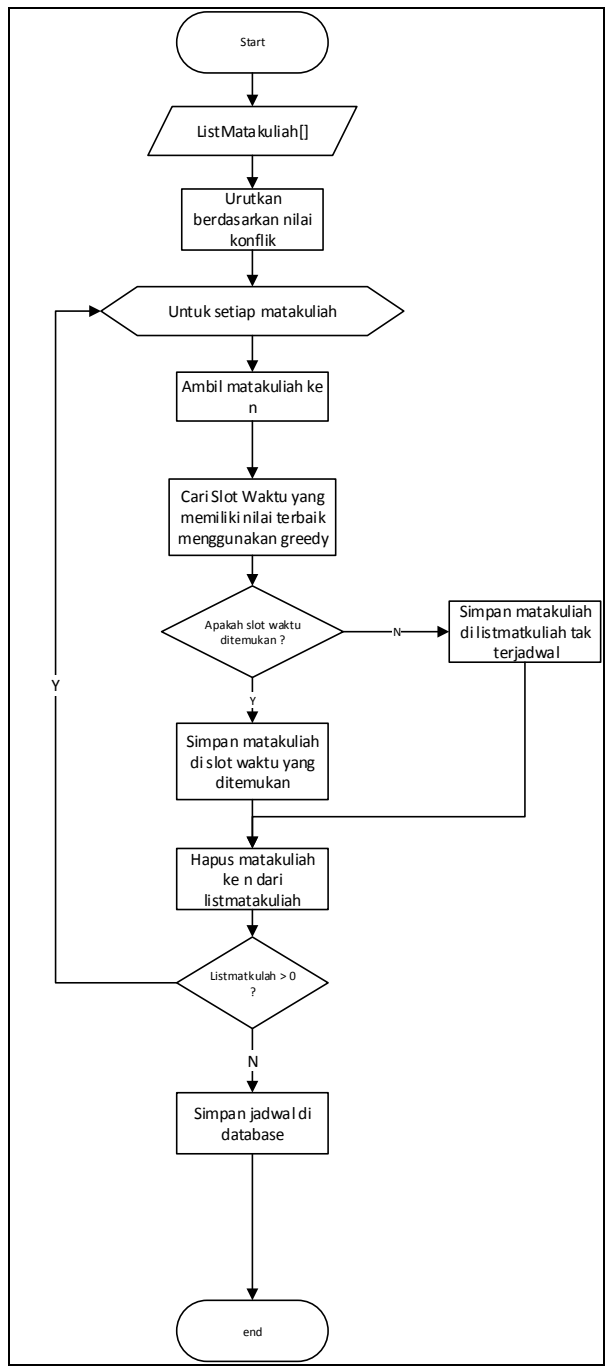

Gambar 1. Flowchart sistem

Berikut adalah langkah dalam proses kerja sistem penjadwalan matakuliah menggunakan algoritma greedy

1. Langkah pertama adalah membuat list matakuliah yang akan di masukan ke dalam jadwal

2. Langkah ke dua urutkan matakuliah berdasarkan nilai konflik terbesar
3. Langkah ketiga pilih matakuliah yang paling tinggi nilai konfliknya

4. Langkah ke empat cari slot waktu yang memiliki nilai terbaik menggunakan algoritma greedy

5. Langkah kelima jika slot watu di temukan maka hapus matakuliah tersebut di dalam list matakuliah, jika slot waktu tidak di temukan maka mata kuliah tersebut di simpan dalam list matakuliah tak terjadwal

6. Langkah ke 6 simpan matakuliah yang telah menemukan slot waktu ke dalam database

\section{Studi Kasus}

Komponen penjadwalan yang digunakan (dosen, ruangan, matakuliah, dan kelas matakuliah) kemudian menentukan nilai bobot konflik dengan cara sebagai berikut :

$\mathrm{N} 1$ = constraint ruangan $: 0.1 /$ banyak constraint ruangan;

$\mathrm{N} 2$ = constraint waktu dosen dapat mengajar :0.45 / Cd (banyak constraint waktu/sks matakuliah)

N 3 = type kelas : jika kelas matakuliah dapat digabung nilainya 0.45 jika tidak bernilai 0

Nilai_conflict $=\mathrm{N} 1+\mathrm{N} 2+\mathrm{N} 3$

\section{Contoh Kasus Perhitungan Greedy :}

Diketahui :

- Matakuliah 1 Tingkat 1 = M1 (tipe kelas : Mandiri, Sks : 4, Jumlah mahasiswa : 40)

- Matakuliah 2 Tingkat 1 = M2 (tipe kelas : Mandiri, Sks : 2, Jumlah mahasiswa : 30)

- Matakuliah 3 Tingkat 1 = M1 (tipe kelas : Mandiri, Sks : 4, Jumlah mahasiswa : 30)

Kelas : A

Ruangan :

- R1, Kapasitas 60

- R2, Kapasitas 30

- R3, Kapasitas 30

Dosen :

- D1, Constraint waktu : -.

- D2, Constraint waktu : -

- D3, Constraint waktu : Senin, jam pertama, kedua, ketiga, dan keempat.

Rumus perhitungan yang digunakan adalah : 
- Nilai Konflik (NC) : N1+N2+N3

Dimana :

- $\mathrm{N} 1$ = constraint ruangan : $0.1 /$ banyak constraint ruangan;

- $\mathrm{N} 2=$ constraint waktu dosen dapat mengajar : 0.45 / CD

- $\mathrm{N} 3=$ tipe kelas (jika kelas matakuliah dapat digabung nilainya 0.45 jika tidak bernilai 0)

- $\mathrm{CD}=$ banyak constraint waktu dosen/sks matakuliah

Kualitas Slot Waktu : P1+P2+P3

Dimana :

- $\mathrm{P} 1=$ Check apakah pada hari di slot ini kelas tersebut telah melaksanakan kuliah atau belum, jika telah melaksakan kuliah beri nilai 0.40

- $\mathrm{P} 2=$ Check apakah pada hari di slot ini dosen yang mengajar telah mengajar suatu kuliah atau belum, jika telah melaksakan kuliah beri nilai 0.35

- $\mathrm{P} 3$ = lihat apakah pada hari dan jam yang sama pada slot ini terdapat kelas yang sama dengan 1 angkatan di atas / di bawahnya. Jika iya beri nilai 0.25 .

Penjadwalan

1. Pengurutan dari nilai constraint tertinggi agar menempati ruang/ waktu yang sesuai

2. Mendahulukan pengurutan matakuliah tingkat awal

3. Mendahulukan pengurutan dosen dengan jadwal mengajar paling banyak

Nilai konflik matakuliah :

M1 Kelas A diajar oleh D1 = M1AD1.

Jumlah mahasiswa $=60$.

Maka :

$$
\begin{aligned}
& \circ \mathrm{N} 1=0.1 / 1=0.1 \\
& \circ \mathrm{N} 2=0.45 /(0 / 4)=0 \\
& \circ \mathrm{N} 3=0 \\
& \circ \mathrm{NC}=0.1+0+0=0.1
\end{aligned}
$$

M2 Kelas A diajar oleh D2 = M2AD2. Jumlah mahasiswa $=30$.

Maka :

$$
\begin{aligned}
& \circ \mathrm{N} 1=0.1 / 0=0 \\
& \circ \mathrm{N} 2=0.45 /(0 / 2)=0
\end{aligned}
$$

$$
\begin{aligned}
& \circ \mathrm{N} 3=0 \\
& \circ \mathrm{NC}=0+0+0=0
\end{aligned}
$$

M3 Kelas A diajar oleh D3 $=$ M3AD3. Jumlah mahasiswa $=30$.

Maka :

$$
\begin{aligned}
& \circ \mathrm{N} 1=0.1 / 0=0 \\
& \circ \mathrm{N} 2=0.45 /(4 / 4)=0.45 \\
& \circ \mathrm{N} 3=0 \\
& \circ \mathrm{NC}=0+0.45+0=0.45
\end{aligned}
$$

Hasil Pengurutan dari niali konflik terbesar :

$\begin{array}{ll}\text { 1. } & \mathrm{M} 3 \mathrm{AD} 3 \\ \text { 2. } & \mathrm{M} 1 \mathrm{AD} 1 \\ \text { 3. } & \mathrm{M} 2 \mathrm{AD} 2\end{array}$

\section{M3AD3}

Constraint waktu ajar $=[1.2,1.3,1.4,1.5]$

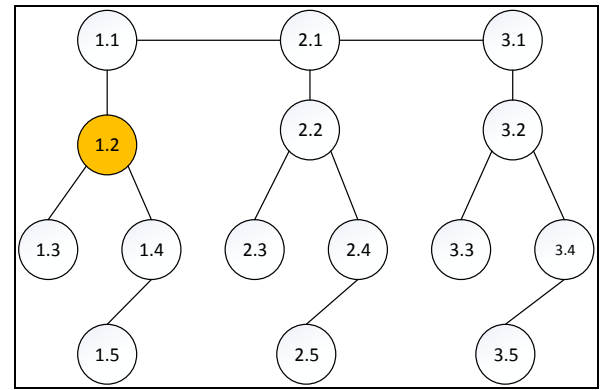

Cari nilai $\mathrm{f}$ curNode [1.2] = cari nilai kualitas slot Penjadwalan
a. $\quad \mathrm{P} 1=0$
b. $\mathrm{P} 2=0$
c. $\quad \mathrm{P} 3=0$
d. nilai kualitas Slot Penjadwalan $=\mathrm{P} 1+\mathrm{P} 2+\mathrm{P} 3=0$
e. $\mathrm{F}=0$

Berdasarkan constraint waktu mengajar dosen matakuliah M3AD3 dapat diljadwalkan pada slot 12 (senin jam ke 2 hingga jam ke 5 (4Sks pelajaran)). Dilakukan pengecekan ruang yang akan digunakan. Karena Kelas matakuliah tidak memiliki constraint ruangan maka dilakukan pengecekan ketersedian ruangan R1, R2 dan R3 pada slot tersebut dimana R2 pada slot 1.2 tersedia, sehingga matakuliah dapat dijadwalkan pada waktu tersebut. Jadwal terpilih Senin Jam ke 2 Pada Ruangan R2

\begin{tabular}{|c|c|c|c|}
\hline \multicolumn{4}{|c|}{ Senin } \\
\hline Jam & Matakuliah & Dosen & Ruangan \\
\hline 08.00-12.00 & M3 & D3 & R2 \\
\hline
\end{tabular}

Yasmin Math Khader, Youllia Indrawaty Nurhasanah, Afriyanti Dwi Kartika 


\section{M1AD1}

Constraint Ruangan [R1]

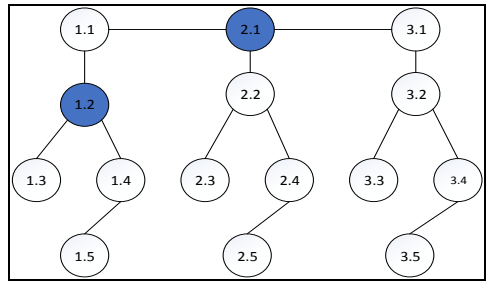

Cari nilai $\mathrm{f}$ node $1.1=$ cari nilai kualitas Slot Penjadwalan
a. $\mathrm{P} 1=0.40$
b. $\mathrm{P} 2=0$
c. $\mathrm{P} 3=0$
d. nilai kualitas Slot Penjadwalan $=\mathrm{P} 1+\mathrm{P} 2+\mathrm{P} 3=0.40$
e. $\mathrm{F}=0.40$

Dari hasil nilai f node (1.1) yang bernilai lebih dari nol dilakukan proses buka node tetangga pada slot $1.1(2.1,1.2)$

Hitung f untuk 2,1
a. $\mathrm{P} 1=0$
b. $\mathrm{P} 2=0$
c. $\mathrm{P} 3=0$
d. $\mathrm{F}=$ Nilai Kualitas Slot Jadwal $=0$

M1AD1 dapat diljadwalkan pada slot 2.1 (selasa jam ke 1 hingga jam ke 4 (4Sks pelajaran)). Dilakukan pengecekan ruang yang akan digunakan. Karena Kelas matakuliah memiliki constraint ruangan(R1) maka hanya dilakukan ketersedian ruangan R1 dislot tersebut dimana R1 pada slot 2.1 kosong sehingga perkuliahan dapat di jadwalkan pada slot tersebut. Jadwal terpilih Selasa Jam ke 1 Pada Ruangan R3.

\begin{tabular}{|c|c|c|c|}
\hline \multicolumn{4}{|c|}{ Selasa } \\
\hline Jam & Matakuliah & Dosen & Ruangan \\
\hline 07.00-11.00 & M1 & D1 & R3 \\
\hline
\end{tabular}

M2AD2

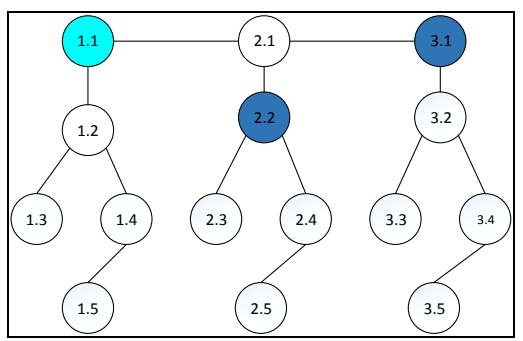

Cari nilai $\mathrm{f}$ curNode [1.1] = cari nilai kualitas Slot Penjadwalan
a. $\mathrm{P} 1=0.40$
b. $\mathrm{P} 2=0$
c. $\mathrm{P} 3=0$
d. nilai kualitas Slot Penjadwalan $=\mathrm{P} 1+\mathrm{P} 2+\mathrm{P} 3=0.40$
e. $\mathrm{F}=0$

Dari hasil f node [1.1] lebih dari nol dilakukan proses buka node berikutnya.

Hitung f untuk 2.1
a. $\mathrm{P} 1=40$
b. $\mathrm{P} 2=0$
c. $\mathrm{P} 3=0$
d. F=Nilai Kualitas Slot Jadwal $=40$

Dari hasil f node [2.1] lebih dari nol maka masuk ke proses buka node tetangga pada slot [3.1]

Hitung f untuk 3.1
a. $\mathrm{P} 1=0$
b. $\mathrm{P} 2=0$
c. $\mathrm{P} 3=0$
d. F=Nilai Kualitas Slot Jadwal $=0$

M2AD2 dapat diljadwalkan pada slot 3.1 (Rabu jam ke 1 hingga jam ke 2 (2Sks pelajaran)). Dilakukan pengecekan ruang yang akan digunakan. Dilakukan pengecekan ketersedian ruangan R1,R2,R3 dislot tersebut dimana R2 pada slot 3.1 kosong dan mencukupi kapasitas untuk menampung kelas matakuliah M2AD2 sehingga perkuliahan dapat di jadwalkan pada slot tersebut. Jadwal terpilih Rabu Jam ke 1 Pada Ruangan R2.

\begin{tabular}{|c|c|c|c|}
\hline \multicolumn{4}{|c|}{ Rabu } \\
\hline Jam & Matakuliah & Dosen & Ruangan \\
\hline 07.00-09.00 & M2 & D2 & R3 \\
\hline
\end{tabular}

III.4 Implementasi Sistem dan User Interface 
Berdasarkan dari hasil rancangan maka pada sistem ini terdapat beberapa menu, yaitu menu Penjadwalan, Data Kandidat yang di dalamnya termasuk menu halaman Dosen, Matakuliah, Ruangan, Kelas Matakuliah, serta menu Kalender, dan Jadwal Dosen.

Hasil dari penjadwalan matakuliah dengan ketentuan Data Ruang, Data Matakuliah, Data Dosen yang di proses dengan algoritma greedy di halaman kalender.

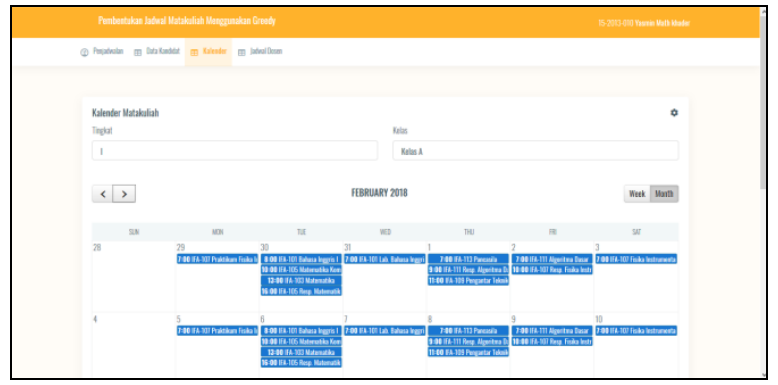

\section{Pengujian Implementasi}

Dari 165 kelas mata kuliah dengan jumlah 50 mata kuliah, lima ruangan mata kuliah penjurusan informatika, tiga ruangan bahasa inggris, satu ruangan khusus laboratorium fisika, satu ruangan khusus laboratorium bahasa inggris, satu ruangan khusus laboratorium dasar komputer, satu ruangan khusus laboratorium, satu ruangan khusus laboratorium jaringan komputer, satu ruangan khusus laboratorium multimedia, dan dengan total 30 staff pengajar yang terdiri dari 19 dosen tetap, empat asisten dosen, dan tujuh dosen tidak tetap. Sistem berhasil menjadwalkan semua kelas mata kuliah.

\section{KESIMPULAN DAN SARAN}

Kesimpulan yang didapat dari penelitian ini adalah sistem pendukung keputusan penjadwalan mata kuliah dengan model pemrograman heuristic menggunakan algoritma $A^{*}$ ini menghasilkan solusi jadwal mata kuliah yang dapat menjadi pertimbangan pengambil keputusan (decision maker) dalam membangun jadwal mata kuliah.

\section{REFERENSI}

Adiguna R, 2018, Implementasi Algoritma Genetika Pada Sistem Penjadwalan Perkuliahan.
Teknik Informatika, Institut Teknologi Nasional.

Alamsyah, Indriani Tiara Putri. 2014. Penerapan Algoritma Greedy Pada Mesin Penjual Otomatis (Vending Machine). Fakultas Teknik. Unversitas Negeri Semarang.

Ayu W, Djunaidy A dan Aulia R. 2013. Penjadwalan Mata Kuliah Menggunakan Algoritma Genetika di Jurusan Sistem Informasi ITS Jurusan Sistem Informasi. Fakultas Teknologi Informasi, Institut Teknologi Sepuluh Nopember.

Baker, Kenneth R. 2009. Principles of Sequencing and Scheduling. United States.

Wiley Faridzqi I, 2017. Sistem Informasi Penjadwalan Perkuliahan Pada Universitas Pendidikan Indonesia Kampus Tasikmalaya Menggunakan Algoritma Genetika. Program Studi Sistem Informasi, Fakultas Teknik dan Ilmu Komputer, Universitas Komputer Indonesia.

Herli A, Indra Kharisma Raharjana, Purbandini. 2015. Sistem Pencarian Hotel Berdasarkan Rute Perjalanan Terpendek Dengan mempertimbangkan Daya Tarik Wisata Menggunakan Algoritma Greedy. Jurusan Sistem Informasi, Fakultas Sains dan Teknologi, Universitas Airlangga.

Haryadi D dan Jamal A. 2015. Preferensi Dosen Pada Proses Penjadwalan Kuliah Menggunakan Algoritma Genetik Studi Kasus: Universitas Al Azhar Indonesia. Program Studi Teknik Informatika, Fakultas Sains dan Teknologi. Universitas Al Azhar Indonesia.

Jakaria R, Rosid M. 2017. Implementasi Algoritma Greedy Pada Metode Transportasi Dengan Menggunakan Vam Dalam Pendistribusian Produk. Program Studi Teknik Informatika, Universitas Muhammadiyah Sidoarjo Indonesia.

Kesuma A. 2013. Penerapan Algoritma Greedy untuk Menentukan Penjadwalan Kelas Gedung Labtek $V$. Jurusan Teknik Informatika, Institut Teknologi Bandung.

Morton, Thomas dan David W Pentico. 2001. Heuristic Schedulling System With Aplications to Production System \& Project Management. New York. JohnWiley \& Sons, Inc. 